Jurnal Ekonomi dan Bisnis Islam, Vol. 4, No. 1, Januari-Juni 2018

\title{
KONSEP PENGELOLAAN KEUANGAN ISLAM MENURUT PEMIKIRAN ABU UBAID
}

\author{
Mohammad Ghozali \\ Fakultas Syariah dan Pasca Sarjana \\ Universitas Darussalam Gontor \\ Email: mohammadghozali@unida.gontor.ac.id
}

\author{
Ria Khoirunnisa \\ Fakultas Syariah dan Pasca Sarjana \\ Universitas Darussalam Gontor \\ Emal: riakhoirunnisa21@gmail.com
}

\section{ARTICLE HISTORY}

Received:

14 Oktober 2018

Accepted:

1 November 2018

Online available:

2 November 2018

Keywords:

Management of Public Finances of Abu Ubayd, Baitul Maal,

\section{ABSTRACT}

In the concept of Baitul Maal it is balance budget. The concept that emphasizes on the balance between the budget accepted by the budget issued. In the management of State finances, the Messenger as the leader is always trying to implement policies aimed at kemashlahatan of the Muslims. Abu Ubaid in Al-Amwal, who explained that the distribution of wealth in a fair and equitable should be based on the principles of good fiscal justice and perfect as possible. One of the biggest sources of funding over the financing of all government spending gained at this time is through taxes. In Indonesia it is the backbone of the tax revenue of the State. Therefore, in order for tax not incriminating peng in the community then the Government of Indonesia to make related the poll rules. The existence of such a regulation is expected to appropriate tax proportional voting so that no one is harmed. This research uses a type of research literature (library research) with the theoretical approach. This research study using the method of analysis and critique of the study research. This research using primary and secondary data. Methods of data analysis, using inductive techniques descriptive. The results of this research is the essence of thought Abu Ubaid on managing the finances of the State.

\section{ABSTRAK}

Dalam konsep Baitul Maal yaitu balance budget. Konsep yang menekankan pada keseimbangan antara anggaran yang diterima dengan budget yang dikeluarkan. Dalam pengelolaan keuangan 
Kata Kunci:

Pengelolaan

Keuangan Publik

Abu Ubaid, Baitul

Maal negara, Rasulullah sebagai kepala negara menerapkan kebijakankebijakan yang bertujuan pada kemashlahatan ummat. Abu Ubaid dalam Kitab Al-Amwal, yang menjelaskan bahwa pendistribusian kekayaan secara adil dan merata harus berdasarkan prinsip-prinsip keadilan fiscal yang baik dan sempurna mungkin. Salah satu sumber pendanaan terbesar atas pembiayaan semua pengeluaran pemerintah yang didapat saat ini adalah melalui pajak. Di Indonesia pajak merupakan salah satu pendapatan negara. Oleh karena itu, dalam pemungutan pajak agar tidak memberatkan masyarakat maka dibuatlah aturan-aturan terkait pemungutannya. Dengan adanya peraturan tersebut diharapkan pemungutan pajak sesuai proporsional sehingga tidak ada yang dirugikan. Penelitian ini menggunakan jenis penelitian literatur (library research) dengan pendekatan teoritis. Penelitian ini menggunakan metode studi analisa kritik dan kajian penelitian. Penelitian ini menggunakan data primer dan sekunder. Metode analisis data, dengan menggunakan teknik induktif deskriptif. Hasil penelitian ini adalah intisari pemikiran Abu Ubaid tentang pengelolaan keuangan negara.

\section{PENDAHULUAN}

Dalam sebuah Negara yang berbasis kapitalisme kita akan dapati ada banyak masalah di bidang keuangan dari lembaga-lembaga sektor publik pemerintah dalam system kapitelisme. Masalah telah muncul dalam anggaran negara dalam berita seperti masalah tidak mencapai target pajak penghasilan target oleh pemerintah. Serta penyerapan anggaran rendah negara anggaran. Dalam hal pengeluaran anggaran cenderung lebih tinggi dari realitas situasi. Fakta itu telah menyebabkan penurunan dalam pentingnya analisis standar pengeluaran. Penggunaan anggaran negara bertujuan untuk meringankan masalah ekonomi makro tidak telah mengejar (Deliarnov, 2014).

Pada kenyataannya, dengan anggaran negara ini, masalah ekonomi makro negara dikurangi oleh berbagai isu. seperti rendah pertumbuhan ekonomi, kemiskinan, pengangguran, ketidaksetaraan pendapatan, inflasi dan utang luar negeri, defisit anggaran, industri build-up dan pertumbuhan lebih terpusat. Sayangnya, sebuah APBN yang merupakan alat penting dalam perekonomian yang tidak berfungsi. Sebagai hasil dari penelitian ini, pengelolaan ekonomi Islam melalui Baitul Mal dengan menggunakan konsep balance budget mampu berhasil dalam peningkatan anggaran Negara (P3EI, 2008).

Salah satu sarjana-sarjana Muslim yang berkontribusi pada pemikiran ekonomi adalah Abu Ubaid berbicara dalam bukunya sering tentang keuangan publik dan makroekonomi solusi pemecahan masalah. Pengaruh ide dan pendapat ketika Abu Ubaid tinggal di Tarsus yang ia memperoleh manfaat dari masalah tanah dan pajak baik (Karim 2015). Kitab "Al-Amwal" ditulis 
Ghozali dan Khoirunnisa | Jurnal Ekonomi dan Bisnis Islam, Vol. 4, No. 1, Januari-Juni 2018

oleh Abu Ubaid pada isu-isu yang berkaitan dengan pengenaan pajak, undang-undang pertanahan, hukum administratif dan hukum internasional. Buku ini memberikan banyak informasi penting pada keberhasilan pemerintah dalam menerapkan berbagai kebijakan seperti keberhasilan Umar Ibn Khattab pemerintah dalam membangun landasan sistem pajak, jadi peneliti dalam berpikir Abu Ubaid ingin sistem pajak karena anggaran pendapatan negara terbesar untuk Indonesia adalah pajak (Al Kaaf, 2002).

Harus diakui bahwa anggaran negara yang menganut system kapitalisme seperti di Indonesia masih belum lengkap dan situasi ini telah menyebabkan masalah makroekonomi diringankan. Untuk ini, proyek paparan anggaran negara harus didasarkan pada teori-teori Islam untuk memecahkan masalah makro ekonomi negara. Teori Abu Ubaid menjadikan salah satu pikiran dan referensi Indonesia. Maka dengan penelitian ini mampu bertahap reformasi situasi pengelolaan keuangan negara Indonesia.

\section{Metodelogi Kajian}

Kajian ini jenis penelitian literatur (library research) dengan pendekatan teoritis yang digunakan. Kajian ini menggunakan metode studi analisa kritik dan kajian penelitian. Kajian ini i menggunakan data primer dan sekunder. Metode analisis data, dengan menggunakan teknik induktif deskriptif. Tulisan ini adalah pengkajian terhadap metodologi penafsiran yang ditempuh sang penulis dengan terlebih dahulu menelusuri secara singkat biografi kehidupan penulis, perjalanan intelektualnya dan metode dalam kitab Al-Amwal.

Teknik yang digunakan pada makalah ini adalah deskriptif analisis. Deskriptif berarti teknik dengan cara menjelaskan konsep Ekonomi Islam tentang konsep kebijakan fiscal yang terkait dengan pengelolaan keuangan public secara apa adanya tanpa interpretasi dari kajian ini. Setelah itu, Kajian ini mencoba mengkomparasikan konsep ini agar dapat diambil sebuah kesimpulan yang komprehensif mengenai kebijakan pengelolaan keuangan public dalam Perspektif Islam menurut pandangan Abu Ubaid pengelolaan keuangan public.

\section{LITERATURE REVIEW}

\section{Pandangan Ekonomi Abu Ubaid}

\section{Filosofi Hukum dari Sisi Ekonomi}

Dalam isi buku Abu Ubaid perlu dipandang dari sisi filsafat hukum maka akan tampak bahwa dia menekankan keadilan sebagai prinsip utama. Menurut Pandangan Abu Ubaid pengimplementasian dari prinsip ini akan membawa kepada kesejahteraan ekonomi dan keselarasan sosial. Pada dasarnya Pandangan Abu Ubaid memiliki pendekatan yang berimbang kepada hak-hak individual, publik dan Negara. Jika kepentingan individual berbenturan dengan kepentingan publik maka ia akan berpihak pada kepentingan publik (Al Haritsi, 2006). 


\section{Konsep Pengelolaan Keuangan Islam ...}

Pandangan pikiran Abu Ubaid lahir pada masa kuatnya Dinasti Abbasiyah dan tidak ada sebuah masalah legitimasi, sehingga hasil pemikirannya sering kali ditekankan kearah kebijakan khalifah untuk membuat keputusan (dengan kehati-hatian). Kewenangan Khalifah memilih di antara alternatif pandangannya asalkan dalam tindakannya itu berdasarkan pada ajaran Islam dan mengarahkan pada kemaslahatan kaum Muslim, yang tidak ada kepentingan pribadi. Sebagai contoh, Abu Ubaid memberikan pendapat bahwa zakat dari tabungan dapat diberikan pada negara ataupun penerimanya sendiri, sedangkan zakat komoditas harus diberikan kepada pemerintah, jika tidak maka kewajiban agama diasumsikan tidak ditunaikan (Amalia, 2007).

Lebih jauh, dalam pandangan Abu Ubaid bahwa seorang Imam memiliki otoritas dalam memutuskan, untuk kepentingan publik, seperti membagi tanah taklukan pada para penakluk ataupun membiarkan kepemilikannya pada penduduk setempat atau lokal adalah termasuk dalam hal tersebut.

Hal yang serupa dengan otoritas tersebut dalam alokasi dari khams, ia menyebutkan bahwa apabila mendesaknya kepentingan publik, maka imam yang adil dapat memperluas batasan-batasan yang telah ditentukan.

Akan tetapi di sisi yang lain, Abu Ubaid secara tegas menekankan bahwa perbendaharaan negara harus digunakan untuk kepentingan atau kemanfaatan publik, tidak boleh disalahgunakan atau dimanfaatkan oleh penguasa untuk kepentingan pribadinya.

Dalam pembahas tentang tarif atau persentase untuk pajak tanah dan poll-tax, pentingnya keseimbangan antara kekuatan finansial dari subyek non Muslim, dalam finansial modern disebut sebagai "capacity to pay" (kemampuan membayar) dan juga memperhatikan kepentingan para penerima Muslim.

Pasukan kaum Muslim yang melewati di atas tanah subjek non Muslim dilarang untuk ditarik uang atau biaya yang melebihi apa yang diperbolehkan oleh perjanjian perdamaian.

Berkenaan dengan tarif pajak kontraktual tidak dapat dinaikkan tapi dapat diturunkan jika terjadi ketidakmampuan membayar serius. Selain itu jika permohonan pembebasan hutang disaksikan oleh saksi muslim, maka komoditas komersial subyek muslim setara dengan jumlah hutangnya itu akan dibebaskan dari cukai. di satu sisi lainnya pengumpul kharaj, jizyah, zakat tidak boleh menyiksa subyeknya dan di sisi lain bahwa para subyek harus memenuhi kewajiban finansialnya secara teratur dan sewajarnya (Muhammad, 2002). Artinya Abu Ubaid menjelaskan upaya untuk menghentikan terjadinya diskriminasi atau penindasan dalam perpajakan serta terjadinya penghindaran terhadap pajak.

Pada beberapa kasus Abu Ubaid tidak merujuk pada kharaj yang pernah terjadi di masa khalifah Umar ataupun tidak melihat adanya permasalahan dalam meningkatkan ataupun menurunkannya berdasarkan situasi dan kondisi yang membuat kita berpikir bahwa Abu Ubaid mengadopsi keberagaman aturan atau hukum karena perbedaan waktu atau periode tidak bias 
Ghozali dan Khoirunnisa | Jurnal Ekonomi dan Bisnis Islam, Vol. 4, No. 1, Januari-Juni 2018

dielakkan. Akan tetapi keberagaman tersebut sah apabila aturan atau hukum tersebut diputuskan melalui suatu ijtihad yang didasarkan pada nash.

\section{Sumber Penerimaan Keuangan Publik}

Menurut Kitab al-Amwal secara khusus menjelaskan mengenai keuangan publik (public finance), titik beratnya adalah pada praktek yang dilakukan Rasulullah dan Khalifaur Rasyidin, terutama Umar bin Khattab sebagai semple ideal dalam pengelolaan keuangan publik. Institusi yang mengelola disebut Baitul Mal.

Istilah Baitul Mal muncul setelah perang badar, menurut pendapat yang diunggulkan (Qaul Rajih), yaitu kaum muslimin mendapatkan harta rampasan perang (ghanimah) yang banyak dan pada waktu itu tempat penyimpanan kekayaan negara sepertighanimah, shadaqah dan $f a^{\prime} i$ adalah mesjid (Rozalinda, 2016).

Dalam perkembangan beberapa saat kemudian sumber penerimaan keuangan publik pun bertambah, seperti kharaj, 'ursy dan khumus. Selain itu fa'i, yaitu berupa harta benda dan tanah yang mereka serahkan tanpa melalui peperangan. Yang menjadi landasan adalah firman Allah dalam surah al-Hasyr : 6, yang artinya:

"Dan apa saja harta rampasan perang (fa'i) yang diberikan Allah kepada Rasul-Nya (dari harta benda) mereka, maka untuk mendapatkan itu kamu tidak mengerahkan seekor kuda pun dan (tidak pula) seekor unta pun, tetapi Allah yang memberikan kekuasaan kepada Rasul-Nya terhadap siapa yang dikehendaki-Nya".

Menurut An-Nabhani (2009) harta shafi yang Rasulullah saw pilih dari ghanimah yang diberikan kaum muslimin sebelum harta itu dibagikan. Sebagaimana riwayat Ibnu Abbas dari Rasulullah saw, "Berikanlah dari harta ghanimah bagian Rasulullah dan shafi". Harta 1/5 dari ghanimah yang telah dibagi.

Menurut hadits yang diriwayatkan dari Abi 'Aliyah, ia berkata: "Rasulullah saw mengumpulkan ghanimah dan beliau dibagi, ketika ada sesuatu yang jatuh Nabi menempatkannya bagian untuk Ka'bah, bagian untuk Baitullah, kemudian membagi sisa 1/5, untuk Nabi satu bagian, ahli kerabat satu bagian, anak yatim satu bagian, orang miskin satu bagian dan ibnu sabil satu bagian. Abi 'Aliyah berkata yang Nabi jadikan satu bagian untuk Ka'bah adalah bagian Allah."

Namun yang perlu diketahui bahwa sebagaimana menurut takwil Umar bin-Khattab, ada tiga harta yang masuk dalam keuangan publik, yaitu: shadaqoh, fa'i dan khumus.

\section{a. Shadaqoh/Zakat}

Shadaqoh wajib yang memiliki istilah lain zakat harta seperti zakat emas, perniagaan, unta, sapi, kambing, biji-bijian dan buah-buahan. Zakat harta ini dialokasikan kepada delapan golongan yang telah Allah nyatakan dalam Al-quran, tidak seorang pun 
berhak atas zakat tersebut kecuali mereka dan merupakan kewajiban pada setiap harta apabila telah mencapai nisab dan haul untuk dikeluarkan zakatnya (Nasution et al, 2006).

Pandangan Abu Ubaid dalam mendeskripsikan permasalahan sumber keuangan publik secara luas dan mendalam. Hal ini bias dilihat dari pemikiran beliau pada permasalahn sekitar penerimaan keuangan Negara.

Namun yang perlu diketahui, Abu Ubaid mengungkapkan ketentuan yang disepakati (tidak ada ikhtilaf), yaitu apabila seseorang memiliki harta yang wajib dizakati diantaranya 200 dirham, 20 dinar, 5 ekor unta, 30 ekor sapi, atau 40 ekor kambing.

Konsekuensinya, bila seseorang memiliki salah satu di atas dari awal haul sampai akhir, maka ia wajib mengeluarkan zakatnya yang dinamakan nishab oleh Imam Malik dan penduduk Madinah sedangkan penduduk Iraq menyebutnya asal harta (Amalia, 2007).

\section{b. Fa'i}

Fa'i menurut bahasa adalah ar-Rujuu' berarti kembali, sedang menurut istilah fiqh adalah sesuatu yang diambil dari harta ahli kitab dengan cara damai tanpa peperangan atau setelah peperangan itu berakhir, disebut $f a^{\prime} i$ karena Allah mengembalikan harta tersebut kepada kaum muslimin.

Sedang menurut versi Abu Ubaid adalah sesuatu yang diambil dari harta dzimmah perdamaian atas jizyah dari mereka, yang sebab itu jiwa mereka dilindungi dan dihormati. Harta $f a^{\prime} i$ digunakan untuk kepentingan pemerintahan dan kesejahteraan umat (Chaudry, 2016).

\section{c. Kharaj}

Kharaj menurut bahasa al-ghullah yaitu penghasilan atau tanah taklukan kaum muslimin dengan jalan damai yang pemilknya menawarkan untuk mengolah tanah itu sebagai pengganti sewa tanah dan bersedia memberikan sebagian dari hasil produksinya. Jumlah kharajnya setengah dari hasil produksi.

\section{d. Jizyah}

Jizyah adalah pajak tahunan yang wajib dibayarkan oleh seorang non-muslim khusunya ahli kitab, untuk jaminan perlindungan jiwa, properti, ibadah dan harta merdeka atau budak yang tinggal di wilayah pemerintahan Islam.

Menurut Karim (2006) Rasulullah ketika memerintahkan kepada Muadz ibn Jabal atas ahli kitab di Yaman besarnya jizyah bagi masing-masing kepala adalah:

1. 1 dinar atau

2. 30 ekor sapi - jizyahnya 1 ekor tabi' [sapi umur 1 tahun]

3. 40 ekor sapi - jizyahnya 1 ekor musinah 
Ghozali dan Khoirunnisa | Jurnal Ekonomi dan Bisnis Islam, Vol. 4, No. 1, Januari-Juni 2018

4. Penghasilan dari tanah $1 / 10$ bila diairi dengan hujan dan $1 / 5$ bila menggunakan biaya.

Diantara ahli kitab yang membayar jizyah yaitu penduduk Najran yang beragama Kristen. Kewajiban membayar jizyah akan hilang setelah masuk Islam.

Persamaan antara kharaj dan jizyah merupakan kewajiban atas ahli dzimmah dan dibelanjakan berdasarkan penggunaan harta fa'i, perbedaannya jizyah itu atas kepala dan kharaj atas tanah, jizyah gugur saat masuk Islam, dan kharaj tidak.

\section{e. Khumus}

Khumusmenurut Abu Ubaid adalah 1/5 ghanimah dari ahli harbi, rikaz, dan luqathah. Dalam pembahasan khumus Abu Ubaid menyebutkan bahwa harta yang terkena khumus, pertama, beliau menafsirkan itu ghanimah, sesuai dengan firman Allah surat Al-Anfal ayat 41. Kedua, khumus dari harta yang diperoleh melalui penambangan dan harta yang terpendam (rikaz). Ketiga, khumus pada harta yang dipendam hal, sebagaimana terjadi ketika mujahid dari as'sya'abi dimana seorang laki-laki menemukan 1000 dinar yang dipendam di luar kota, kemudian datang kepadanya Umar, dan Umar mengambil 1/5 dari harta itu sebesar 200 dinar dan sisanya diberikan pada orang yang menemukan. Kemudian 200 dinar itu dibagikan kepada kaum muslimin.

Namun yang perlu diketahui bahwa Abu Ubaid menyatakan bahwa ada tiga hukum yang dilakukan Umar kepada harta benda yang dipendam. Pertama, bahwa harta itu diambil khumusnya dan sisanya diberikan kepada yang menemukannya. Kedua, yang menemukan tidak diberikan harta itu, namun diserahkan seluruhnya kepada Baitul Mal. Ketiga, harta itu seluruhnya diberikan kepada yang menemukan dan tidak diserahkan ke Baitul Mal (Karim, 2006).

\section{f. 'Usyr}

Al-'usyr merupakan jama' dari kata 'usyrun yaitu satu bagian dari sepuluh. Sedangkan menurut fuqoha terdapat dua pengertian, pertama 'usyr zakat yaitu sesuatu yang diambil pada zakat tanaman dan buah-buahan (Q.S. Al-An'am: 141). Kedua, 'usyradalah sesuatu yang diambil dari harta kafir dzimmi yang melintas untuk perniagaan.

\section{Zakat}

\section{Hubungan antara Zakat dan Politik (Kekuasaan)}

Menurut Ugi (2004), karakter politis zakat adalah karakter yang menjadikan zakat sebagai institusi keuangan publik. Namun, ia merupakan institusi keuangan publik yang khas karena ia memiliki karakter religius. Meskipun pada masa Nabi, kedua karakteristik zakat itu disatukan, namun setelah Nabi wafat, ada fenomena di mana keduanya diperlakukan secara terpisah. 
Peran Abu Bakar yang menjelaskan kedua karakteristik zakat dan meskipun melalui usahanya karakteristik religius dan polisi zakat ditetapkan.

Masalah apakah zakat dibayarkan kepada pemerintah dan bukan kepada Nabi, muncul pada masa khalifah Abu Bakar ketika beberapa kabilah Arab menolak membayarkan zakatnya setelah wafatnya Nabi. Qardhawi (2004) menyebutkan bahwa alasan mereka menolak membayar zakat setelah Nabi wafat karena mereka menganggap perjanjian mereka dengan Nabi tentang kewajiban syahadat, shalat dan zakat telah batal dengan wafatnya orang yang dalam perjanjian.

Hal itu disebabkan sikap kabilah-kabilah itu bermacam-macam. Di antaranya ada yang megakui nabi-nabi palsu, ada yang tidak mengakui syariat Islam dan menghindari kewajiban shalat dan zakat semuanya, ada pula yang mengakui shalat dan sayriat-syariat Islam lainnya tetapi masih ragu-ragu menerima zakat.

Hal tersebut di atas dikarenakan mereka baru memeluk Islam dan masih terpengaruh oleh kehidupan badui mereka, bukan karena belum mengerti zakat. Atas dasar itu, Imam Abu Sulaiman Khattabi dan lainnya menggolongkan mereka "pembangkang" bukan "murtad", walaupun mereka juga tidak mengakui zakat itu wajib setelah Nabi wafat (Qardhawi, 2004).

Sunnah telah membedakan antara keduanya. Tidaklah kalian melihat bahwa Nabi kadang mengirim pengumpu zakat (mushaddiq) ke (para pemilik) binatang ternak dan mengambil darinya baik dengan rela (rida) atau terpaksa (kurh).

Hal yang sama juga dilakukan oleh para pemimpin negara setelah beliau. Dan atas dasar ini, Abu Bakar memerangi mereka yang tidak mau (membayar) zakat binatang ternak. Tidak ada pentunjuk bahwa Nabi dan khalifah-khalifah setelahnya memaksa orang membayar zakat uang (sadaqat al-samit). Sebaliknya, mereka (masyarakat muslim) lebih membayarnya tanpa paksaan, sebagaimana ia diamanahkan kepada mereka untuk membayarnya (Suharto, 2004).

Berdasarkan hal-hal di atas, dapat dipahami dengan cukup jelas bahwa zakat memiliki 2 (dua) karakter yang berbeda. Karakter politis zakat, menjadi alasan pemerintah atau penguasa politik dalam melakukan upaya untuk menjamin zakat dapat dijalankan dengan baik, khususnya pada harta yang tampak (amwal zahiriyah).

Sedangkan karakter religius zakat lebih memberikan penekanan kepada kesadaran dari masing-masing individu muslim untuk membayar zakat dari hartanya yang tidak tampak (amwal batiniyah).

Pemerintah tidak memiliki otoritas untuk memaksa para muzakki agar membayar zakat atas segala jenis harta yang tidak tampak (amwal batihiyah). Abu Bakar dalam hal ini memiliki peran yang sangat penting dalam menjaga karakter zakat, khususnya karakter politisnya.

Abu Bakar telah mengambil keputusan yang tepat dalam hal memerangi para pembangkang zakat. Jika Abu Bakar tidak memerangi para pembangkang zakat, maka karakter 
Ghozali dan Khoirunnisa | Jurnal Ekonomi dan Bisnis Islam, Vol. 4, No. 1, Januari-Juni 2018

politis zakat akan punah, sehingga zakat hanya dipandang sebagai sebuah kewajiban invidivu dan penyalurannya dapat dilakukan secara invidivu juga (Rozalinda, 2016).

\section{Pembelanjaan Penerimaan Keuangan Publik}

Dalam masalah distribusi pendapatan memegang erat kaitannya antara penerimaan dan pembelanjaan/pengalokasian untuk kepentingan publik. Abu Ubaid dalam Kitab al-Amwal nya begitu jelas dan transparan dalam membahas masalah keuangan publik terkait sekitar masalah penerimaan dan pembelanjaan.

Dalam karim (2006), Abu Ubaid menyebutkan kaidah mendasar dalam membatasi orang yang berhak atas kekayaan publik. Dengan menukil pendapat Umar sebagaimana diriwayatkan dari Aslam, ia berkata,"Telah berkata Umar ra bahwa tidak seirang muslim kecuali hak atas harta menerima atau menolak, setelah itu Umar membacakan surah (al-Hasyr : 7-10) dan berkata Umar: ayat ini memuat semuanya (manusia) dan tidak tersisa seorang muslim kecuali ia mendapat hak akan harta itu (harta fa'i). Menurut riwayat Ibnu Syibah bahwa ketika Umar membentuk dewan membagi para istri Rasulullah saw yang dinikahi 12.000 dirham, bagian juwairiyah dan shafiyah 6.000 dirham (karena keduanya fa'i dari Allah untuk Rasul-Nya) kaum muhajirin syahid Badar masing-masing 5.000 dirham dan kaum anshar yang syahid 4.000 dirham."

Selanjutnya, bahwa zakat diambil dari mereka yang kaya dan dikembalikan kepada mereka yang membutuhkan, yaitu delapan golongan yang disebut dalam al-Qur'an. Menurut Ugi Suharto (2004), bagaimanpun pendistribusian harta dalam Islam itu sangat penting dimana Rasulullah telah memberi batasan, yaitu seseorang yang memikul tanggungan (hidup) kaumnya, seseorang yang tertimpa musibah besar dan memusnahkan harta bendanya dan seseorang yang tertimpa kemiskinan.

Dalam pendistribusian pengeluaran dari penerimaan khumus (khumus ghanimah, khumus, barang tambang dan rikaz serta khumus lainnya) adalah ketentuan dari Rasulullah saw dan pendistribusiannya kapan dan untuk siapa tentu juga dengan ketentuan Rasulullah. Karena dana-dana publik merupakan kekayaan publik, maka dialokasikan untuk kesejahteraan publik seperti kesejahteraan anak-anak, korban bencana, santunan dan lainnya.

\section{Kepemilikan: Pandangan Kebijakan Perbaikan Pertanian.}

Sesuatu yang baru dalam hubungan antara kepemilikan dengan kebijakan perbaikan pertanian secara implisit ditemukan oleh Abu Ubaid. Menurutnya, kebijakan pemerintahan seperti itu terhadap tanah gurun dan deklarasi resmi terhadap kepemilikan individual dari tanah tandus atau tanah yang sedang diusahakan kesuburannya atau diperbaiki sebagai insentif untuk meningkatkan produksi pertanian, maka tanah yang diberikan dengan persyaratan untuk ditanami dibebaskan dari kewajiban membayar pajak (Boedi, 2010).

Tidak cukup disebut sebagai kepemilikan sepetak tanah mati dan hanya dengan menggali sebuah sumur lalu meninggalkannya begitu saja. Apabila tanah tidak diberdayakan atau 
ditanami tiga tahun berturut-turut hanya dari sumber air tersebut yang dapat dimiliki, sedangkan yang lainnya menjadi terbuka untuk direklamasi dan selanjutnya ditempati orang lain.

Jadi, menurut Abu Ubaid sumber dari publik seperti sumber air, pada rumput penggembalaan dan tambang minyak tidak boleh pernah dimonopoli seperti pada tanah pribadi. Semua sumber daya ini hanya dapat dimasukkan ke dalam kepemilikan negara yang digunakan untuk pelayanan masyarakat (An-Nabhani, 1990).

Adapun hukum - hukum pertanahan yang dikemukakan oleh Abu Ubaid terdiri dari :

\section{a. Iqtha',}

Menurut Huda (2011) lqtha' adalah tanah yang oleh kepala negara diberikan kepada seorang rakyat untuk menguasai sebidang tanah dengan mengabaikan yang lainnya. Dalam kitab Al-Amwal, Abu Ubaid menafsirkan tanah biasa yang bisa dijadikan iqtha' dan yang tidak bisa. Dan biasanya setiap daerah/tanah yang dihuni pada masa yang lama, kemudian ditinggalkan penghuninya maka keputusan hukum tanah itu diserahkan kepada kepala negara.

Dari penjelasan di atas, menurut Abu Ubaid mengenai 'iqtha hendaknya pemerintah tidak meng-'iqtha tanah kharaj. Alasannya karena tanah kharaj adalah tanah yang produktif memberikan hasil dan menambah devisa negara.

Dan di sisi lain dengan mempetakan tanah bukan kharaj dapat memberikan manfaat untuk bagi para pengembalaan hewan ternak, dimana hal ini dapat menambah pertambahan produksi hewan yang sama pentingnya dengan masalah pertanian.

\section{b. Ihya' al-Mawat}

Yaitu mengembalikan kembali tanah yang mati, tandus, tidak terurus, tidak ada pemiliknya dan tidak dimanfaatkan dengan cara membersihkannya, mengairi, mendirikan bangunan dan menanam kembali benih-benih kehidupan pada tanah tersebut.

Dalam hal ini negara berhak menguasai tanah tersebut dengan menjadikannya milik umum dan manfaatnya diserahkan untuk kemaslahatan umat (Karim, 2007).

\section{c. Hima (perlindungan)}

Menurut Euis Amalia (2010) maksud dari Hima yaitu lahan untuk tempat mengembala hewan-hewan ternak, yang tidak berpenduduk yang dilindungi negara. Dimana tanah hima ini adalah tanah yang mendapat perlindungan dari pemerintah, namun dapat dimanfaatkan oleh seluruh umat hasil yang ada pada tanah tersebut seperti air, rumput dan tanaman, hal ini sesuai dengan sabda Rasulullah, "Orang muslim adalah saudara bagi muslim yang lainnya, yang memberi mereka keleluasaan air dan rumput". 
Ghozali dan Khoirunnisa | Jurnal Ekonomi dan Bisnis Islam, Vol. 4, No. 1, Januari-Juni 2018

\section{Fungsi Uang.}

Menurut Abu Ubaid ada dua fungsi uang -yang yang tidak sebagaimana difahami orang kinian, dimana tidak mempunyai nilai intrinsik- sebagai standar dari nilai pertukaran (standard of exchange value) dan sebagai media pertukaran (medium of exchange).

Tampak jelas bahwa dengan pendekatan ini menunjukkan dukungan Abu Ubaid terhadap teori ekonomi mengenai yang logam. Dengan merujuk pada kegunaan umum dan relatif konstannya nilai emas dan perak dibanding dengan komoditas yang lain. Apabila kedua benda tersebut digunakan sebagian komoditas maka nilainya akan dapat berubah-ubah pula karena dalam hal tersebut keduanya akan memainkan peran yang berbeda sebagai barang yang harus dinilai atau sebagai standar penilaian dari barang lainnya (Karim, 2004).

Walaupun Abu Ubaid secara implisit mengakui adanya fungsi tersebut ketika membahas tentang jumlah tabungan minimum tahunan yang wajib terkena zakat dan jumlah zakatnya, tidak menyebutkan fungsi penyimpanan nilai (store of 'value) dari emas dan perak (Boedi, 2010)

\section{Ekspor Impor}

Pemikiran Abu Ubaid dapat dibagi kepada tiga bagian tentang ekspor impor ini, yaitu tidak adanya nol tarif dalam perdagangan internasional, cukai bahan makanan pokok lebih murah, dan ada batas tertentu untuk dikenakan cukai.

\section{a. Tidak Adanya Nol Tarif}

Pengumpulan cukai merupakan kebiasaan pada zaman jahiliah dan telah dilakukan oleh para raja bangsa Arab dan non Arab tanpa pengecualian. Sebab, kebiasaan mereka adalah memungut cukai barang dagangan impor atas harta mereka, apabila masuk ke dalam negeri mereka.

Dari Abdurrahman bin Maqil, ia berkata, "Saya pernah bertanya kepada Ziyad bin Hudair, Siapakah yang telah kalian pungut cukai barang impornya? la berkata, "Kami tidak pernah mengenakan cukai atas Muslim dan Mua-hid. Saya bertanya, Lantas, siapakah orang yang telah engkau kenakan cukai atasnya? la berkata, "Kami mengenakan cukai atas para pedagang kafir harbi, sebagaimana mereka telah memungut barang impor kami apabila kami masuk dan mendatangi negeri mereka".

Dari uraian di atas, Abu Ubaid mengambil kesimpulan bahwa cukai merupakan adat kebiasaan yang senantiasa diberlakukan pada zaman jahiliah. Kemudian Allah membatalkan sistem cukai tersebut dengan pengutusan Rasulullah dan agama Islam. Lalu, datanglah kewajiban membayar zakat sebanyak seperempat dari usyur (2.5\%).

Dari Ziyad bin Hudair, ia berkata, "Saya telah dilantik Umar menjadi petugas bea cukai. Lalu dia memerintahkanku supaya mengambil cukai barang impor dari para pedagang kafir harbi sebanyak usyur (10\%), barang impor pedagang ahli dzimmah sebanyak setengah dari usyur (5\%), dan barang impor pedagang kaum muslimin seperempat dari usyur (2.5\%)". 


\section{Konsep Pengelolaan Keuangan Islam ...}

\section{b. Cukai Bahan Makanan Pokok}

Untuk minyak dan gandum yang merupakan bahan makanan pokok, cukai yang dikenakan bukan $10 \%$ tetapi $5 \%$ dengan tujuan agar barang impor berupa makanan pokok banyak berdatangan ke Madinah sebagai pusat pemerintahan saat itu.

Dari Salim bin Abdullah bin Umar dari ayahnya, ia berkata, "Umar telah memungut cukai dari kalangan pedagang luar; masing-masing dari minyak dan gandum dikenakan bayaran cukai sebanyak setengah dari usyur (5\%). Hal ini bertujuan supaya barang impor terus berdatangan ke negeri madinah. Dan dia telah memungut cukai dari barang impor alQithniyyah sebanyak usyur (10\%)"(Karim, 2006).

\section{c. Ada Batas Tertentu untuk Cukai}

Sesuatu yang sangat menarik, tidak semua barang dagangan dipungut cukainya. Ada batas-batas tertentu dimana kalau kurang dari batas tersebut, maka cukai tidak akan dipungut.

Dari Ruzaiq bin Hayyan ad-Damisyqi (dia adalah petugas cukai di perbatasan Mesir pada saat itu) bahwa Umar bin Abdul Aziz telah menulis surat kepadanya, yang isinya adalah:

"Barang siapa yang melewatimu dari kalangan ahli zimmah, maka pu-ngutlah barang dagangan impor mereka. Yaitu, pada setiap dua puluh dinar mesti dikenakan cukai sebanyak satu dinar. Apabila kadarnya kurang dari jumlah tersebut, maka hitunglah dengan kadar kekurangannya, sehingga ia mencapai sepuluh dinar. Apabila barang dagangannya kurang dari sepertiga dinar, maka janganlah engkau memungut apapun darinya. Kemudian buatkanlah surat pembayaran cukai kepada mereka bahwa pengumpulan cukai akan tetap diberlakukan sehingga sampai satu tahun" (Huda, 2011).

Jumlah sepuluh dinar adalah sama dengan jumlah seratus dirham di dalam ketentuan pembayaran zakat. Seorang ulama Iraq, Sufyan telah menggugurkan kewajiban membayar cukai apabila barang impor ahli dzimmah tidak mencapai seratus dirham. Menurut Abu Ubaid, seratus dirham inilah ketentuan kadar terendah pengumpulan cukai atas harta impor ahli dzimmah dan kafir harbi.

\section{SIMPULAN}

Abu Ubaid menyatakan bahwa fungsi uang tidak mempunyai nilai intrinsic sebagai standar dari nilai pertukaran (standard of exchange value) dan sebagai media pertukaran (medium of exchange). la merujuk pada kegunaan umum dan relative konstannya nilai emas dan perak dibanding dengan komoditas yang lain.

Hal ini sangat berbanding terbalik dengan keadaan sekarang yang dimana fungsi uang merupakan sebagai media pertukaran yang sah dan di terima oleh masyarakat.

Pandangan-pandangan Abu Ubaid merefleksikan perlunya memelihara dan mempertahankan hak dan kewajiban masyarakat, menjadikan keadilan sebagai prinsip utama dalam menjalankan roda kebijakan pemerintah, serta menekankan rasa persatuan dan 
Ghozali dan Khoirunnisa | Jurnal Ekonomi dan Bisnis Islam, Vol. 4, No. 1, Januari-Juni 2018

tanggung jawab bersama. Disamping itu, menyatakan bahwa pemerintah wajib memberikan jaminan standar kehidupan yang layak bagi setiap individu dalam sebuah masyarakat muslim. Abu Ubaid mengatakan bahwa penerimaan negara (fai', khumus, shadaqah dan zakat) wajib dikelola negara dan mengalokasikannya kepada masyarakat.

Administrasi keuangan Abu Ubaid adalah bahwa dia adalah bapak dari filosofi hukum dan menekankan keadilan sebagai prinsip utama. 1) ekuitas dari pajak tanah, abses, Anshor, dan milik umum pelaksanaan prinsip ini akan mengakibatkan kesejahteraan ekonomi. (2) keseimbangan sosial Abu Ubaid pemandangan berfokus pada keadilan antara Muslim dan nonMuslim.

\section{DAFTAR PUSTAKA}

Amalia, DR. Euis. (2010). Sejarah Pemikiran Ekonomi Islam dari Masa Klasik Hingga Kontenporer. Jakarta: Gramata Publishing.

Al Qasim, Abu Ubaid. (1988). Kitab al Amwal, Beirut: Dar al Fikr.

Al-Haritsi, Jaribah bin Ahmad, (2006). Fikih Ekonomi Umar bin Khattab, Penerjamah H. Asmuni Solihan Zamakhsyari, Jakarta: Khallifah.

An-Nabhani, Taqyuddin, (1990). An-Nizham al-Iqtishad fi al-Islam, Beirut: Dar al-Ummah.

Al-Kaaf, Abdullah Zakiy. (2002). Ekonomi dalaam Perspektif Islam. Bandung: Pustaka Setia.

Basri, Yuswar Zainul \& Mulyadi Sabri, (2005). Keuangan Negara dan Analisis Kebijakan Utang Luar Negeri. Jakarta: PT. Raja Grafindo Persada.

Boedi, Abdullah. (2010), Peradaban Pemikiran Ekonomi Islam. Bandung: Pustaka Setia.

Chaundhry, Muhammad Sharif, (2011). Sistem Ekonomi Islam, Jakarta: Prenada Media Group.

Deliarnov, (2014). Perkembangan Pemikiran Ekonomi Edisi Ketiga, Jakarta: PT Raja Grafindo Persada.

Hendri Tanjung, Dosen Pascasarjana UIKA Bogor dan Peneliti Tamu FEM IPB dalamshariaeconomicforum, 2012.

Huda, Nurul \& Ahmad Muti, (2011). Keuangan Publik Islam Pendekatan al-Karaj (Imam Abu Yusuf), Bogor: Penerbit Ghalia Indonesia.

Karim, Adiwarman. (2001). Ekonomi Islam: Suatu Kajian Ekonomi Makro. Jakarta: Karim Business Consulting.

Karim, Adiwarman. 2004, 2006, 2008. Sejarah Pemikiran Ekonomi Islam. Jakarta: Rajawali Pers

Kemenkeu, (2014). Perkembangan Perekonomian dan Kebijakan APBN 2014. Jakarta: FEB UNILA.

Muhammad, (2002). Kebijakan Fiskal dan Moneter dalam Ekonomi Islam, Jakarta: Salemba Empat. 
P.Eko Prasetyo, Fundamental Makro Ekonomi, Yogyakarta: Beta Offset.

Pusat Pengkajian dan Pengembangan Ekonomi Islam (P3EI) UIN Jogja. (2009). Ekonomi Islam, Jakarta: RajaWali Press.

Qardhawi, Yusuf. (2004). Hukum Zakat (terjemahan dari buku Fiqhuz Zakat). Jakarta:Pustaka Litera AntarNusa.

Rozalinda, (2016). Ekonomi Islam (Teori dan Aplikasinya pada Aktivitas Ekonomi, Jakarta: PT. Raja Grafindo.

Suharto, Ugi. (2004). Keuangan Publik Islam: Reinterpretasi Zakat dan Pajak. Studi Kitab AlAmwal Abu Ubayd. Cetakan Pertama. Yogyakarta: Pusat Studi Zakat (PSZ). 